\title{
H2BC15 Gene
}

National Cancer Institute

\section{Source}

National Cancer Institute. H2BC15 Gene. NCI Thesaurus. Code C162956.

This gene is involved in DNA accessibility and nucleosome remodeling. 